\title{
Continuous Deep Sea Salt Layer along North Atlantic Margins related to Early Phase of Rifting
}

by

\section{GUY PAUTOT \\ JEAN-MARIE AUZENDE \\ XAVIER LE PICHON}

Centre Océanologique de Bretagne, B.P. $337-29$ N, Brest
- Deep seismic reflexion surveys have revealed diapiric structures in deep water off Labrador, Newfoundland, Mauritania, Morocco, Portugal, Spain and Ireland as well as in the Mediterranean. Many of these diapirs are similar to the Gulf of Mexico salt domes, and it is suggested that there is a continuous deep sea salt layer, off the continental margin, which is related to the early phase of rifting. -
ThE Joides ${ }^{1}$ deep sea drilling into the Challenger knoll in the Gulf of Mexico has proved that the diapirs described by Ewing et al. ${ }^{2}$ were salt domes. Diapirs have also been described in the western Mediterranean ${ }^{4-7}$, off northwest Africa, ${ }^{8,9}$, and off Grand Banks ${ }^{10}$. Doep seismic profiling during recent cruises of the Jean Charcot has enabled us to locate diapirs of the same type off the margin of Laborador, Newfoundland, Morocco and Portugal, in the Bay of Biscay and possibly within Rockall Trough (see Fig. 1). These data suggest the existence off the continental margin of a continuous deep sea salt layer which is related to the early phase of rifting.

\section{Morphology of the Diapirs}

The deep seismic profiling technique which we used is the 'Flexotir', with a hydrophone array of the Institut Français du Pétrole ${ }^{11}$. This enabled us to obtain penetrations of up to 5 a of two way travel time. Consequently, the acoustic basement in our records generally corresponds to the second layer (velocity of about $5 \mathrm{~km} / \mathrm{s}$ ). This ability to penetrate thick sediments down to the basement is essential to investigate the area at the foot of the continental margins where the accumulation of sediments is greatest. Fig. 2 shows photographs of deep seismic profiling records above typical deep sea diapirs. The diapirs are in water depths of 3,000 to $5,000 \mathrm{~m}$ in regions where sedimentary thickness exceeds $3,000 \mathrm{~m}$. They are 6 to $12 \mathrm{~km}$ wide, with steeply sloping walls which seem to originate from below the deepest visible seismic reflector. But in the Mediterranean, for example, their width typically does not exceed 2 to $4 \mathrm{~km}$. They sometimes pierce through the sea floor to form knolls up to several hundred metres high. Adjacent sedimentary strata are usually upturned along the walls of the diapirs. The diapir itself appears as a zone of no acoustic reflexion and its limits are given by the abrupt termination of the adjacent sedimentary strata. Magnetic data, where available, usually show no significant anomalies associated with them.

We describe here the variations in the morphology and the setting of the diapirs in the different deep water marginal zones around the North Atlantic Ocean (see Figs. 1 and 2).

At the Labrador margin (work in preparation) five diapirs have been identified in water $3,000 \mathrm{~m}$ deep apparently over a portion of subsided continental margin (see Fig. $2 A$ ). The sedimentary thickness is at least 2,000 to $4,000 \mathrm{~m}$. The average diameter is $12 \mathrm{~km}$, but the slopes are not very steep. All known diapirs are buried below 1 to $2 \mathrm{~km}$ of sediments. The fact that the basement in this area is not generally very rough and that there are no magnetic anomalies associated with the diapirs suggests that they are not basement intrusions. But these data are among the least convincing.

At the Southern Grand Bank margin (work in preparation), the water depth is $3 \mathrm{~km}$ and the sedimentary thickness is 4 to $5 \mathrm{~km}$. The diameter is rather small, of the order of $6 \mathrm{~km}$. Three known diapirs are deeply buried below $600 \mathrm{~m}$ to $4,000 \mathrm{~m}$ of sediments (see Fig. $2 B$ ).

The Sohm abyssal plain off Grand Banks ${ }^{10}$ has a water depth of $5,250 \mathrm{~m}$ and sedimentary thickness about $5 \mathrm{~km}$, according to our records there. Average diameter is $6 \mathrm{~km}$. Two diapirs pierce the sea floor.

In the Gulf of Mexico ${ }^{2}$ there are numerous diapirs in water $3,500 \mathrm{~m}$ deep. Sedimentary thickness is greater than $5 \mathrm{~km}$ and the diameter is rather large, about $12 \mathrm{~km}$. Some diapirs pierce the sea floor, but the slopes are not very steep (of the order of $10^{\circ}$ ). Along the western margins, there are diapiric ridges which are flat topped and steep sided ${ }^{12}$.

At the Cape Verde Rise", water depth is about $4,000 \mathrm{~m}$. Sedimentary thickness is apparently only $1 \mathrm{~km}$ above acoustic basement according to Fig. 7 of Schneider and Johnson ${ }^{9}$, and the average width is about $2 \mathrm{~km}$, which is much smaller than typical diapirs in the Gulf of Mexico, but is rather similar to the western Mediterranean diapirs.

Between Cape Verde and Canary Island ${ }^{8}$ the water depth varies between $4,700 \mathrm{~m}$ and $5,700 \mathrm{~m}$, and these deep sea diapirs are the furthest from the continental margin (up to $1,300 \mathrm{~km}$ ). Sedimentary thickness is unknown, but it exceeds $1.5 \mathrm{~km}$. Diameter is large, $>10 \mathrm{~km}$, and the slopes are not steep. Some diapirs pierce the surface. Schneider and Johnson' suggest that these diapirs are basement intrusions. This may well be true, for their shape is quite smooth and their distance from the continent is very large.

In the area off northern Morocco and southern Portugal (work in preparation) the water depth is about $4,000 \mathrm{~m}$ (see Fig. 2O). These diapirs are probably the most convincing of all. Sedimentary thickness is at least $4 \mathrm{~km}$, average diameter is $12 \mathrm{~km}$ and the walls are nearly vertical. Within the Horseshoe plain (between the two branches of the Horseshoe seamounts), sedimentary layers have been heavily tectonized and salt tectonism seems to have played a large part there. Some diapirs pierce the sea floor. 


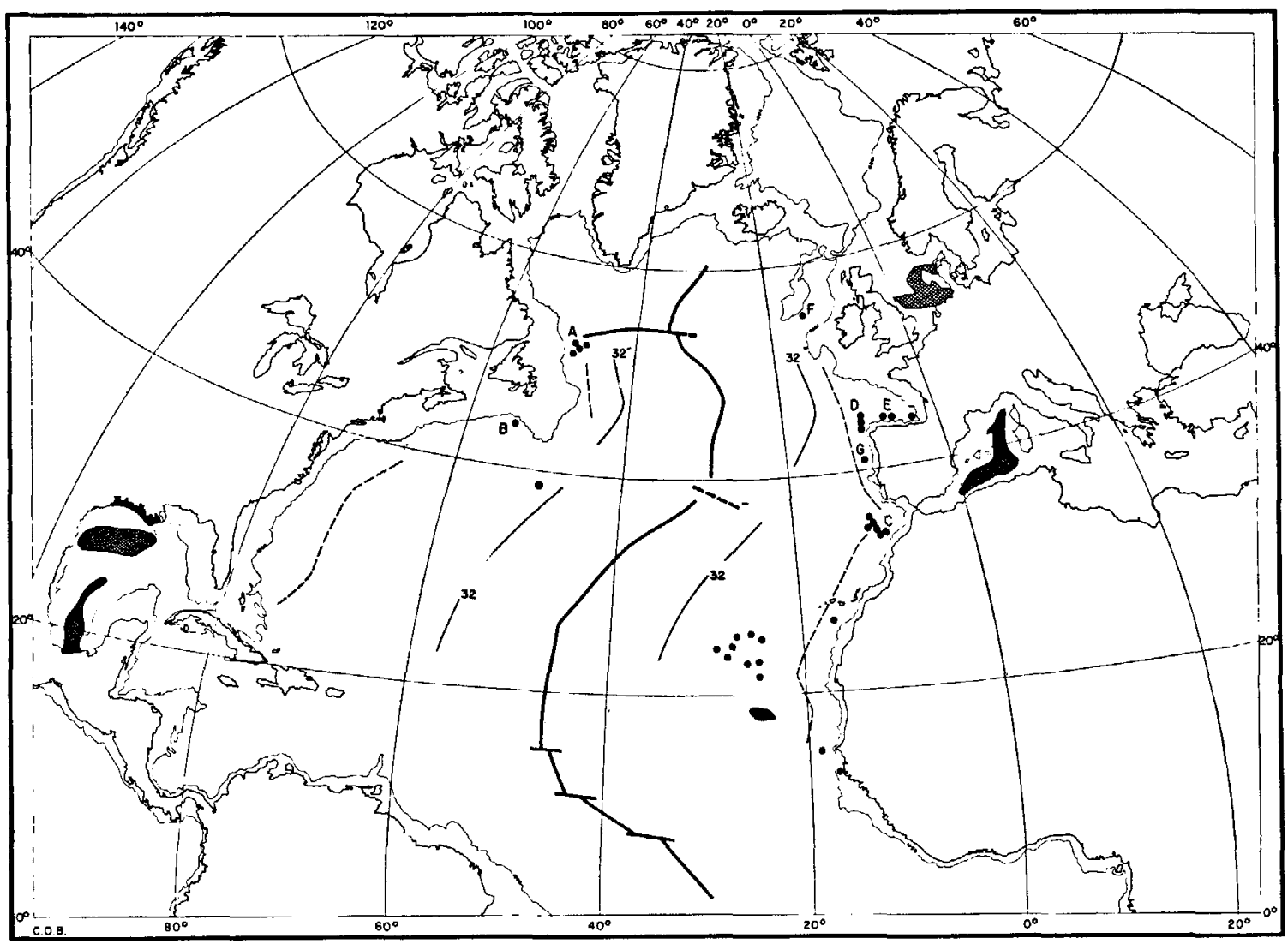

Fig. 1. Distribution of known deep water diapirs in the Gulf of Mexico, the northern Atlantic Ocean and the western Mediterranean. $A, B, C, D, E$ and $F$ refer to Fig. 2.32 refers to anomaly 32 and is shown after Talwant et al. 34 . It gives the approximate limit of crust
older than about 75 m.y. $G$ is for Porto seamount, a probable diapir on which the dredge of shallow water Cretaceous fauna was made.

Diapirs in the Bay of Biscay (work in preparation) are found in the buried trench north of the Spanish margin from the Aquitaine Slope to Galicia Bank, where the water depth is $4,500 \mathrm{~m}$. Sediment thickness generally exceeds $4,000 \mathrm{~m}$. Average diameter is $6 \mathrm{~km}$, and none are known to pierce the sea floor. The walls are nearly vertical (see Fig. $2 D$ and $E$ ).

Only one possible diapir is known in the Rockall Trough (work in preparation). The water is $2,400 \mathrm{~m}$ deep and sediment thickness is about $3,000 \mathrm{~m}$. Its width is 12 $\mathrm{km}$ and it is overlain by $1 \mathrm{~km}$ of sediment. The existence of numerous igneous plugs within the Rockall Trough makes its identification as a salt diapir quite hypothetical (seo Fig. 2F)

Numerous diapirs are known to exist in the western Mediterranean " within the "zone A" of Glangeaud et al. They are usually small (less than $2 \mathrm{~km}$ wide). Some of them pierce the surface. Water depth is about $2,800 \mathrm{~m}$ and sedimentary thickness exceeds $3 \mathrm{~km}$. Outside zone A there are some larger diapirs north of the Baleares. There is a suggestion that in the south-west Mediterranean, they are not domes but ridges ${ }^{13}$. Recently, Bellaiche and Pautot? have described a core taken above a protruding diapir in zone A. Numerous pieces of pyrite were found to be associated with authigenic sulphur. This association of pyrite and authigenic sulphur is often found above caprocks of salt domes ${ }^{14}$.

\section{Age of the Salt Layer}

Several authors ${ }^{8-10}$ have suggested that the formation of this salt layer is related to the formation of the continental margin during the initial phase of rifting of the ocean. Consequently, the formation of the salt layer would be contemporaneous with the initiation of the rifting and there would be no a priori reason to assume that its age is everywhere the same. Actually, in terms of plate tectonics, three main provinces should be recognizable along the Atlantic, the oldest corresponding to the separation of the African plate from the North American plate and the youngest being the separation of the European plate from the North American plate. The separation of the South American from the African plate is intermediary in age. It is more difficult to relate in a simple manner the formation of the Gulf of Mexico and western Mediterranean basin to the dates of initial rifting between the different Atlantic plates, because these basins arose from successive differential movements respectively between the two American plates and the European and African plates.

On the Grand Banks, the salt layer is known to be either Jurassic or Triassic, the caprock being Upper Cretaceous ${ }^{15}$. On the north-west African margin, diapirs of Triassic and Lower Jurassic salt are reported in the Senegal basin'16. In the Aquitaine basin, salt domes of Triassic age are known. In the Gulf of Mexico the Louann salt is of Middle Mesozoic age. Consequently, it is probable that the deep salt layer between the North American and African plates (including the Bay of Biscay) is of Triassic and (or) Jurassic age. On the other hand, it may be more recent, perhaps lower to middle Creteceous, between the North American and European plates, for a middle Cretaceous rifting is suggested for this region ${ }^{17}$. But the known diapirs off Labrador and within the Rockall Trough are not as convincing as the others.

Within the western Mediterranean, two principal phases of extension are suggested by the continental geology: Triassic and Oligo-Miocene. Glangeaud et al. 

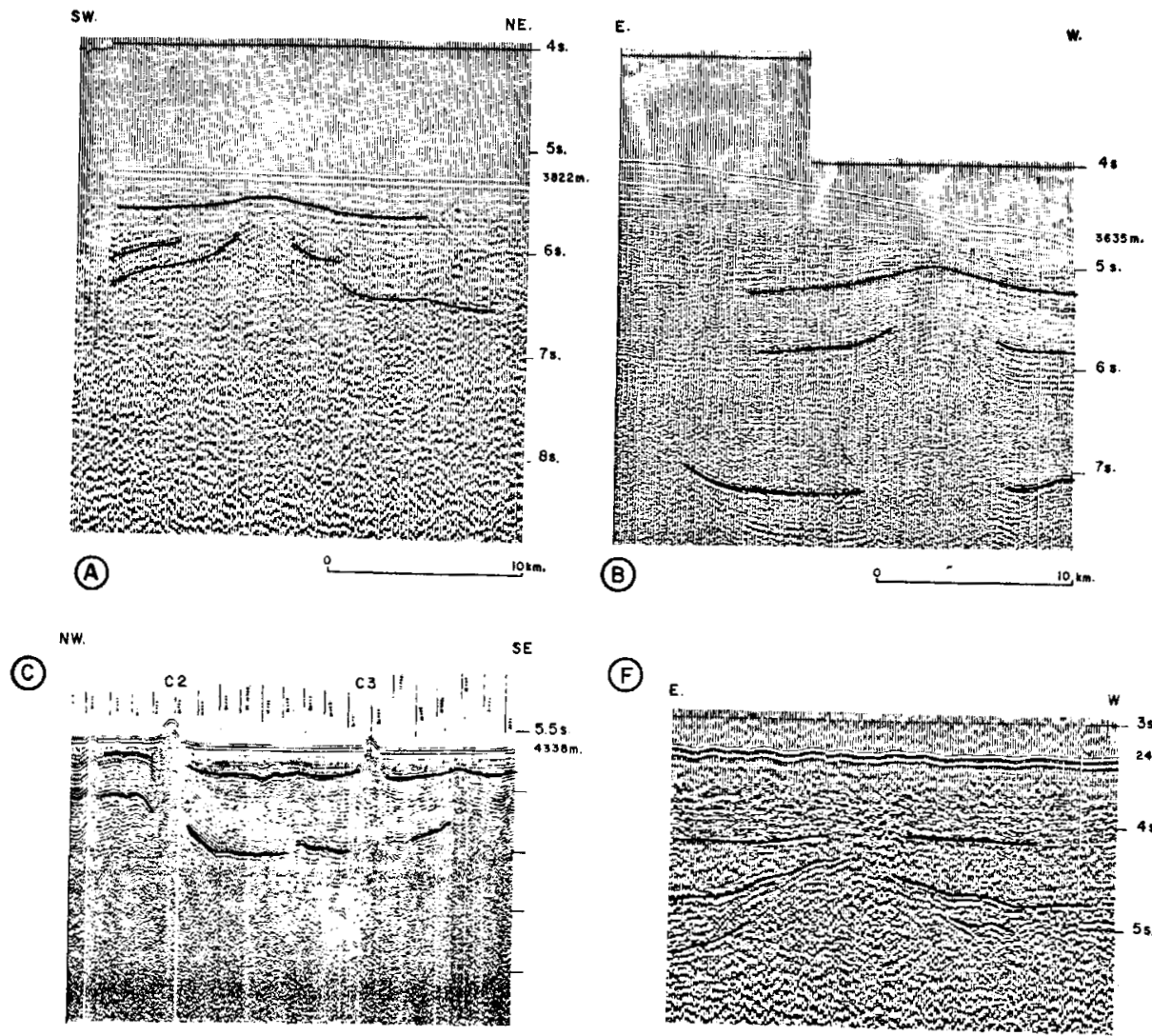

ㄷ.
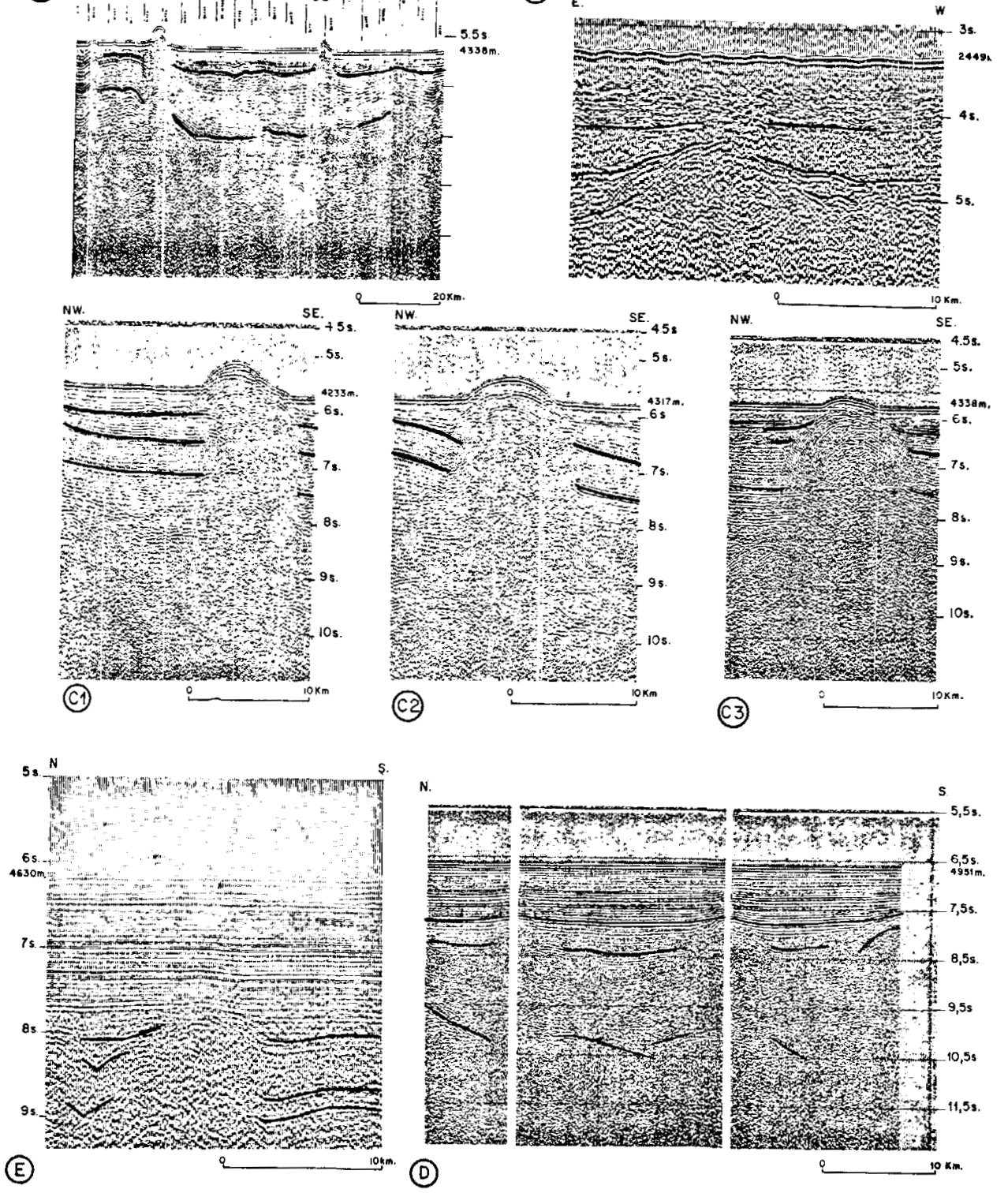

Fig. 2. Photographs of Flexotir records above deep water diapirs obtalned during cruises Noratlante and Nestlante. Letters refor to the location in Fig. 1. vertical exaggeration is about 10 for the variable intensity record. Variable intensity recording with very large exaggeration (up to 30 ) is generally in spite of reproduction loss of resolution. 
have suggested a Triassic age for the salt. Alternatively, Ryan ${ }^{13}$, for example, has suggested an Oligocene age for the salt, which seems more probable with regard to sediment thickness considerstions ${ }^{18}$. Some authors even euggest a Pontian age ${ }^{19}$.

\section{Rifting and Subsidence of the Continental Margin}

An important element for explaining the presence of a thick salt layer in deep water along the continental margin is the widespread evidence of subsidence of the continental margin in the early stages of rifting. This problem has been discussed quite extensively by Heezen ${ }^{20}$, who reports evidence of $5 \mathrm{~km}$ of subsidence of the Bahamas and Florida continental margins during Lower Cretaceous. Similarly, we have dredged between 3,600 and $2,900 \mathrm{~m}$ on the slopes of Porto seamount off Portugal $\left(41^{\circ} 10^{\prime} \mathrm{N}, 10^{\circ} 36^{\prime} \mathrm{W}\right)$ pieces of algal calcarenites which were broken in places and which, according to Dupeuble (personal communication), contain fauna characteristic of the Lower Cretaceous. This is evidence of a post Lower Cretaceous subsidence of at lesst $3,000 \mathrm{~m}$ in this region. General evidence of subsidence along the continental margin is summarized, for example, by Emery ${ }^{21}$. In the Gulf of Mexico, very important subsidence characterizes the Jurassic all along the margin. Similarly, in the western Mediterranean, a Pliocene subsidence of the margins is well documented ${ }^{22}$.

A major problem is to find out whether the subsidence of the continental margin was accompanied by a similar subsidence of the adjacent sea floor, or whether a system of faults between the continental margin and the sea floor allowed a total decoupling of the margin from the sea floor. If there has been some coupling between the North Atlantic continental margins and the adjacent sea floor, the depth of the sea floor must have increased rapidly during Lower and Middle Crecaceous. The results of the Joides drillings off the Bahamas should help to solve this problem. Unfortunately, the Joides report' does not give a clear answer. It does indicate that some important changes happened between Upper Mesozoic and Lower Cenozoic (pages 212, 232, 621). In particular, anaerobic conditions were often prevalent during Lower and Middle Cretaceous and disappeared by Lower Cenozoic (page 232). The ending of the anaerobic conditions is probably related to a rapid progression of the rifting towards the north at the end of the Cretaceous which opened the Atlantic to a cold water sink. This suggests that, before this time, the deep water circulation was rather limited and the deep water temperature rather high as the Atlantic was a closed equatorial basin.

An important indication of the depth of water during Upper Jurassic and Lower Cretaceous is given by the carbonate compensation depth at this time, in spite of the fact that it is difficult to relate an exact depth to this carbonate compensation depth in an environment far different from the present (warmer water, reducing conditions and so on). The Joides report is confusing, however. On page 621 , it is stated that the sediment was always above the carbonate compensation depth, while from the evidence given on page 232 it must have been hovering about the carbonate compensation depth, and from that on pages 552 and 607 it was always below.

It seems that there are some indications of progressive changes in the conditions of sedimentation at the end of Cretaceous and beginning of Tertiary. Because it is difficult to believe that there was complete decoupling of the continental margin from the adjacent deep sea floor, there was most probably continuous deepening of the Atlantic during the Cretaceous. During the Jurassic, the Atlantic was a narrow, closed ocean shallower than today, where conditions were favourable for the deposition of salt, as in the Dead Sea during the Plio-Pleistocene'.

\section{Origin of Salt Layer}

Our data suggest that there is a nearly continuous salt layer in deep water along the North Atlantic continental margins. We have further suggested that this salt layer is related to the initial stage of rifting of the Atlantic and that the origin of the Gulf of Mexico and western Mediterranean salt layers is similarly related to the formation of these basins. The widespread subsidence along the margins some time after the initiation of the rift suggests that this salt was deposited in water shallower than at present. This does not mean, however, that the crust on which the salt was deposited was of continental character. Rather, it was probably a crust similar to the one which underlies the Red Sea ${ }^{23}$. There, three kilometres of selt overlie a $6.5 \mathrm{~km} / \mathrm{s}$ layer which has an oceanic character in relatively shallow water.

Thick salt layers are often associated with subsiding rifts in which the salt lies directly over a volcanic crust. The Afar Triangle is a good example of it. As the rifting proceeds, passing to the Red Sea stage, then to the Gulf of Aden stage, there is rapid subsidence of this quasioceanic crust caused by progressive return of the upper mantle to its normal state. In this model, the initial rifting is marked by a broad elevation ( $2 \mathrm{~km}$ or so) accom. panied by an upturn of the margins of the rift ${ }^{20}$ and conditions favourable to salt deposition within the central rift. One of these conditions is that the drainage pattern is away from the central rifted zone (seo ref. 16, page 114). As the rifting proceeds, general subsidence of the floor of the rift is induced. When the width of the sea exceeds 1,000 to $2,000 \mathrm{~km}$, the drainage pattern is reversed and the water depth along the margins is such that no more salt deposition is possible. Consequently, whereas salt deposition is contemporaneous with the initiation of the rift, general subsidence of the margins occurs later and cannot be used to date the rifting.

Finally, it is interesting to note that most of these deep sea diapirs were formed where sediment thickness is greater than $3 \mathrm{~km}$. This seems to be the minimum overburden necessary to initiate diapir formation in deep water in the absence of other tectonic causes.

This work was supported by the Centro National pour l'Exploitation des Océans. The data were collected on the Jean Charcot with the help of numerous members of the Groupe Scientifique, but especially of Lucien Laubier, chief scientist, and Jacques Martinais, who was in charge of the instrumentation. We thank Mr Chauvin, director of the laboratory, for support and encouragement, and Dr Creighton Burk and Mr Eric Schneider for discussions.

Received April 14, 1970.

- Initial Reports of the Deep Sea Drilling Project, 1 (Nationa IScience Foundation, 1969).

- Ew ing, J., Worzel, J. I., and Ewing, M., J. Geophys. Res., 67, 2059 (1962)

Burck, C. A., Ewing, M., Worzel, J. L., Beall, jun., A. Q., Berggren, W. A. Bukry, D., Fischer, A. G., and Pessagno, jun., E. A., Amer. Assoc.

- Menard, H. W., Smith, S. M., and Pratt, R. M., in Submarine Geology and Qeophysics (edit. by Whittard and Bradshaw), 271 (1965)

- Glangeaud, L., Alinat, J., Polveche, J., Guillaume, A., and Leenhardt, 0. Bull. Soc. Geol, France, 8, 921 (1966)

- Leenhardt, O., Ocean Industry, 4, 50 (1969).

, Bellaiche, G., and Pautot, G., CR Acad. Sci., 267, 991 (1968).

Rona, P. A., Nature, 224, 141 (1969)

- Schnelder, E. D., and Johnson, G. L., Amer. Assoc. Petrol. Geol. (in the press).

10 Watson, J, A., and Johnson, G. L., Ocean Industry, 5, 57 (1970),

1 Damotte, Ch., and Hemon. Ch., Extrait de la revue de l'Institut Francais du Petrole, 24, 1029 (1969).

1" Ballard, J. A., and Feden, R. H., Geol, Soc, Amer, Bull., 8, 505 (1970).

is Ryan, W. B. F., thesis, Columbia Univ. (1969).

14 Mero, J. L., Encyclopedia of Oceanography, 522 (1960)

1s Bartlett, G. A., Maritime Sediments, 5, 4 (1969)

${ }^{16}$ Aymé, J. M., in Salt Basins Around Africa, 83 (Inst. Petroleum, London, 1965).

17 Mayhew, M. A., thesis, Columbia Univ. (1968)

${ }_{18}$ Pautot, G., Marine Geophys. Res. (in the press).

"Cornet, C., CR Sommaires Soc. Geol. France, 5, 149 (1968)

"Heezen, B. C., J. Univ. Missouri at Rolla, 1, 5 (1968).

" Emery, K. O., Southeastern Geol., 9, 173 (1968)

" Bourcart, J., Congrès Géologique International, 190 Session (Alger 1952) (1954).

Tramontini, C., and Davis, D., Geophys. J. Roy. Astro. Soc, 17, 225 (1969).

Taiwani, M., Pitman, W., and Heirtzler, J. R., Eos, 50, 4, 189 (1969). 